\title{
Morphometric characterization of sexual differences in the rat sublingual gland
}

\section{Caracterização morfométrica das diferenças sexuais na glândula sublingual de rato}

\author{
Marta da Cunha Lima* \\ Dagoberto Sottovia-Filho** \\ Tania Mary Cestari*** \\ Rumio Taga****
}

\begin{abstract}
The presence of morphological differences in the sublingual gland of male and female adult rats was determined by morphometry. Absolute and relative glandular mass was $21 \%$ lower and $31 \%$ higher, respectively, in females than in males. The fractions of glandular volume occupied by the mixed acini, intercalated ducts and striated ducts did not differ significantly between genders; however, their absolute volume was respectively 29,42 and 58\% higher in males. Despite the differences in the volume of these morphological compartments, the number of cells did not differ significantly between genders, except for the excretory duct compartment, for which a larger number was observed in males. With respect to cell volume, 13, 33 and 47\% higher volumes were observed in males for mucous acinar cells and striated and excretory duct cells, respectively, while a 38\% higher volume of serous demilune cells was observed for females. The surface-to-volume ratio of acini and striated ducts was respectively 16 and 35\% higher in females. Based on these results, we conclude that the sublingual gland of female rats possesses smaller acini, and shorter ducts whose caliber is narrower, smaller mucous acinar and larger serous cells than the ones found in the male gland, indicating the presence of sexual dimorphism as well as suggesting sexual differences in the quality of the secreted product.
\end{abstract}

DESCRIPTORS: Sublingual gland; Rats; Sex characteristics.

RESUMO: A ocorrência de diferenças morfológicas entre sexos na glândula sublingual de ratos adultos foi verificada pela morfometria. As massas glandular absoluta e relativa das fêmeas foi, respectivamente, $21 \%$ menor e $31 \%$ maior que as dos machos. As frações de volume glandular ocupadas pelos ácinos mistos, ductos intercalares e ductos estriados não mostraram diferenças significantes entre sexos, no entanto, os seus volumes absolutos foram, respectivamente, $29 \%, 42 \%$ e $58 \%$ maiores nos machos. Apesar dessas diferenças nos volumes compartimentais, os seus conteúdos em número de células não apresentaram diferenças significantes entre sexos, exceto o compartimento dos ductos excretores, que mostrou maior número nos machos. Quanto ao volume celular, as células acinosas mucosas, as dos ductos estriados e as dos ductos excretores mostraram volumes, respectivamente, $13 \%$, 33\% e 47\% maiores nos machos, e o das células das semiluas serosas foi 38\% maior nas fêmeas. A relação superficie-volume dos ácinos e dos ductos estriados foi, respectivamente, $16 \%$ e $35 \%$ maior nas fêmeas. Baseados nos resultados obtidos, concluímos que as glândulas sublinguais das fêmeas exibem ácinos menores e ductos mais curtos e menos calibrosos e células acinosas mucosas menores e serosas maiores do que nos machos, indicando a ocorrência de dimorfismo sexual, e sugerindo que possa haver também diferenças na qualidade do produto secretado.

DESCRITORES: Glândula sublingual; Ratos; Características sexuais.

\section{INTRODUCTION}

The sublingual glands are the smallest glands among the major salivary glands of the rat ${ }^{15,21}$. These glands are classified as mixed tubuloacinar glands which are predominantly of the mucous type, i.e., most of their terminal secretory units consist of typical mucous cells and are surrounded by relatively few peripheral serous cells forming the serous demilunes ${ }^{4,6,8,9,17,19,25,26,30}$. The terminal secretory structures are connected to a highly branched duct system which starts with the intercalated ducts, followed by the increasingly larger striated and excretory ducts, and terminating in a single wide-caliber duct which drains into the oral cavity, i.e., the main excretory duct ${ }^{21}$.

\footnotetext{
* DDS; **PhD, Full Professor, Department of Biological Sciences; ${ }^{* * *}$ Graduate Student in Biological Science; Department of Biological Sciences; ${ }^{* * *} \mathrm{PhD}$, Chairman, Laboratory of Histology, Department of Biological Sciences - School of Dentistry of Bauru, University of São Paulo.
} 
Lima MC, Sottovia-Filho D, Cestari TM, Taga R. Morphometric characterization of sexual differences in the rat sublingual gland. Braz Oral Res 2004;18(1):53-8.

The clear predominance of mucous cells in this gland, which depend on a nervous stimulus for secretion of their content and respond to secretagogue-induced stimulation, makes this organ a useful model for the study of the biology of mucus secretion $^{6}$.

Although our group has investigated various aspects of the postnatal development of the rat sublingual gland ${ }^{4,8,9,25,26}$, a study on its quantitative morphology in male and female adult animals is lacking, study which would permit the determination of sexual dimorphism in this gland and the establishment of comparable morphometric parameters for future experimental research.

\section{MATERIAL AND METHODS}

Forty-four 120-day-old Wistar adult rats, obtained from the Central Animal House of the School of Dentistry of Bauru of the University of São Paulo, were used. The rats were divided into three groups of 12 ( 6 males and 6 females), 6 (3 males and 3 females) and 6 ( 3 males and 3 females), used for determination of morphometric dimensions, gland density and shrinkage caused by the histological procedures, respectively. The glands were always collected between 10:00 and 12:00 a.m. to avoid circadian variations. Before anesthesia, each rat was injected intraperitoneally with 1.25 atrophin solution ( $4 \mathrm{mg} / \mathrm{kg}$ body weight, Farmagricola S.A. Importação e Exportação, Mairiporã, SP, Brazil) to prevent salivary secretion. After five minutes, the rat was killed by excessive administration of chlorhydrate of ketamine and xylazine (Agribrands do Brasil Ltda., Paulinea, Brazil). The body mass of each animal was determined and sublingual glands were carefully removed and immediately weighed on an analytical scale. The glands were fixed in phosphate-buffered $10 \%$ formalin solution (Merck KGaA, Darmstadt, Germany) for one week at room temperature, rinsed overnight in running water, dehydrated in ethanol (Merck KGaA, Darmstadt, Germany), cleared in xylene (Merck KGaA, Darmstadt, Germany) and embedded in Histosec (Merck KGaA, Darmstadt, Germany) (paraffin plus plastic resin) melted at $58^{\circ} \mathrm{C}$.

\section{Determination of the processed gland volume}

The volume of the processed gland $(\mathrm{Vp})$ was calculated using the formula $\mathrm{Vp}=(\mathrm{m} / \delta) \cdot \mathrm{Sf}$, where $\mathrm{m}=$ gland mass, $\delta=$ gland density and $\mathrm{Sf}=$ the correction factor for the shrinkage caused by histological processing. The gland density $(\delta)$ was determined by measuring 6 glands of the $2^{\text {nd }}$ group of rats using Mettler Toledo AR 261 Delta Rang scale (Mettler-Toledo GmbH, Greifensee, Switzerland) containing accessories for determination of density, and the shrinkage caused by histological procedures was evaluated in 6 glands of the $3^{\text {rd }}$ group of rats using the method proposed by Taga, $\mathrm{Sesso}^{24}$.

Stereologic measurements of volume density (Vvi), total volume (Vti), surface density (Svi), total surface (Sti), surface-to-volume ratio (s/vi) and absolute cell number (Ni) of each gland structure (i) and of nuclear density $\left(\rho_{\mathrm{ni}}\right)$ of each cell type were taken.

These morphometric measurements were obtained using a Zeiss $8 \mathrm{X}$ eyepiece containing a Zeiss II integration graticule (Carl Zeiss Jena $\mathrm{GmbH}$, Jena, Germany) with 10 parallel lines and 100 points in quadrangular area, and a $100 \mathrm{X}$ oilimmersion objective in an Olympus light microscope (Olympus America Inc., New York, USA). In 50 histological fields per animal, selected by systematic sampling ${ }^{29}$, we counted: a) the number of points (Pi) over the images of each structure (i) and over the entire gland $(\mathrm{P})$; b) the number of points over the nuclei (Pni) and the cytoplasm (Pcyti) of cells in each structure (i); c) the number of nuclei (ni) of each gland structure; d) the number of intersections (Ii) of the contours of the structure with the lines of the graticule; and e) the number of intersections (c) of the nuclei with lines of the graticule. Given the processed gland volume $(\mathrm{Vp})$, the distance between the lines of the graticules (d); the total area examined (A); the total length of the lines of the graticule used (L) and the thickness of the section $(\mathrm{t})$, we calculated with the data obtained in the counts ${ }^{1,29}: \mathrm{Vvi}=\mathrm{Pi} / \mathrm{P}, \mathrm{Vti}=\mathrm{Vvi} \cdot \mathrm{Vp}$, Svi $=2 \mathrm{Ii} / \mathrm{L}, \mathrm{Sti}=\mathrm{Svi} \cdot \mathrm{Vp}, \mathrm{s} / \mathrm{vi}=\mathrm{Svi} / \mathrm{Vvi}, \mathrm{Ni}=(2 \mathrm{ni}$ $\cdot V p) / A[(c / n i) \cdot d+2 t]$, and $\rho_{n i}=$ Pni/Pni + Pcyti.

\section{Determination of the volume of nucleus and cytoplasm of each cell type}

The orthogonal diameters of 50 nuclei of each cell type per rat were measured using a 10 X Ramsden type Olympus eyepiece (Olympus Optical Co. Ltd., Tokio, Japan) and a $100 \mathrm{X}$ oilimmersion objective. The mean nucleus volume was calculated by the formula $\mathrm{Vni}=4 / 3 \pi \cdot r^{3}$. The nuclear volume density $\left(\rho_{\mathrm{ni}}\right)$ determined by the point-counting method, was overestimated because of the Holmes effect ${ }^{29}$. This overestimation was corrected using the correction factor (Ko) calculated by the relationship $\mathrm{Ko}=(1+3 \mathrm{t}) / 2 \mathrm{D}$, where, $\mathrm{D}=$ mean nucleus diameter and $\mathrm{t}=$ section thick- 
Lima MC, Sottovia-Filho D, Cestari TM, Taga R. Morphometric characterization of sexual differences in the rat sublingual gland. Braz Oral Res 2004;18(1):53-8.

ness. The corrected volume densities of the nucleus $\left(\rho_{\text {ni corr }}\right)$ and cytoplasm $\left(\rho_{\text {cyti corr }}\right)$ are $\rho_{\text {ni corr }}=\rho_{\text {ni }} /$ Ko and $\rho_{\text {cyti corr }}=1-\rho_{\text {ni corr }}$. Given the mean volume of the nucleus (Vni), the cytopasmic volume (Vcyti) was calculated by the relationship $\mathrm{Vcyti}=(\mathrm{Vni}$. $\rho_{\text {cyti corr }} / \rho_{\text {ni corr }}$.

\section{Statistical analysis}

The results obtained for male rats were compared to those obtained for females by the Student's $t$-test using the Sigma Stat - Jadel ${ }^{\mathrm{TM}}$ Scientific software for Windows (Jadel Corporation, Chicago, USA) and the level of significance was set at 0.05 . The volume densities were analyzed after arc sin transformation of the original data.

\section{RESULTS}

Body mass, absolute glandular mass, relative glandular mass and gland density data are shown in Table 1. Body mass and absolute glandular mass were respectively 40 and $21 \%$ lower in female rats compared to male animals, while relative glandular mass was $31 \%$ higher in female rats. On the other hand, gland density did not differ between genders, and a mean density of $1.0545 \mathrm{mg} / \mathrm{mm}^{3}$ was observed for the two groups.

The morphometric dimensions of the different sublingual glandular structures obtained for male and female rats are shown in Table 2. A significant difference in volume density, i.e., the fraction of glandular volume occupied by each type of glandular structure, was only observed between genders for the excretory ducts and stroma. This parameter is 1.9 times higher in males and 1.3 times higher in females, respectively. In absolute terms, the compartmental volume of acini, intercalated ducts, striated ducts and excretory ducts was respectively 29, 42, 58 and 155\% higher in male rats. Despite these differences in compartmental volume, the absolute number of cells did not differ between groups for any of the epithelial compartments, except for the excretory ducts where the number of cells was 193\% larger in males compared to females. However, the mean cell volume of mucous acinar cells and striated and excretory duct cells was significantly higher in male rats $(13,33$, and $47 \%$, respectively), while the mean cell volume of serous demilune cells was 38\% higher in females. A significant difference in the total external surface of the various compartments was only observed for the excretory ducts, which was $74 \%$ greater in males. With respect to the surface-to-volume ratio, a 16 and $35 \%$ greater ratio was observed in females for the acini and striated ducts, respectively, indicating that these structures have smaller diameter in females.

The differences in the mean volume of mucous, serous demilune and striated ducts cells and in the diameter of the acini and striated ducts between genders, could be morphologically confirmed comparing Figures $1 \mathrm{~A}$ and $\mathrm{B}$.

\section{DISCUSSION}

Since the discovery by Lacassagne in $1940^{11}$ that the submandibular gland of the laboratory mouse shows a marked sexual dimorphism characterized by the presence of a larger number of developed convoluted granular tubules in males than in females, this gland has been used as a model for the study of various aspects of secondary sexual differences $5,15,17,18$.

Within this line of research, many other studies have been carried out to determine the presence of sexual differences in other major salivary glands of the mouse and, mainly, of other animal species (for a review and references therein, see Pinkstaff ${ }^{17}$ ). Based on these investigations, it became clear that sexual dimorphism in other mouse glands or in the salivary glands of other animals, if present, was not as conspicuous as in the mouse submandibular gland to be characterized by simple morphological analysis of histological sections,

TABLE 1 - Body mass, absolute glandular mass, relative glandular mass and gland density obtained for male and female rats.

\begin{tabular}{l|r|r|r}
\hline \multicolumn{1}{c|}{ Parameter } & Male & Female & Statistical probability \\
\hline Body mass $(\mathrm{g})$ & $362.33 \pm 9.645^{*}$ & $217.31 \pm 6.0287$ & $\mathrm{p}<0.01$ \\
\hline Absolute gland mass $(\mathrm{mg})$ & $78.49 \pm 1.7297$ & $61.64 \pm 2.366$ & $\mathrm{p}<0.01$ \\
\hline Relative gland mass** & $0.22 \pm 0.007$ & $0.28 \pm 0.017$ & $\mathrm{p}<0.01$ \\
\hline Gland density $\left(\mathrm{mg} / \mathrm{mm}^{3}\right)$ & $1.056 \pm 0.002$ & $1.053 \pm 0.001$ & $\mathrm{p}>0.05$ \\
\hline \hline
\end{tabular}

${ }^{*}$ Mean \pm standard error of 6 animals. ${ }^{* *}$ Relative gland mass: ratio between glandular mass and body mass. 
Lima MC, Sottovia-Filho D, Cestari TM, Taga R. Morphometric characterization of sexual differences in the rat sublingual gland. Braz Oral Res 2004;18(1):53-8.

TABLE 2 - Morphometric dimensions of the different sublingual gland structures obtained for male and female rats.

\begin{tabular}{|c|c|c|c|}
\hline Parameter & Male & Female & Statistical probability \\
\hline \multicolumn{4}{|c|}{ Volume density (\%) } \\
\hline Mixed acini & $82.51 \pm 0.897$ & $81.65 \pm 0.861$ & $p>0.05$ \\
\hline Intercalated duct & $0.56 \pm 0.059$ & $0.49 \pm 0.082$ & $\mathrm{p}>0.05$ \\
\hline Striated duct & $3.61 \pm 0.587$ & $2.87 \pm 0.293$ & $\mathrm{p}>0.05$ \\
\hline Excretory duct & $2.88 \pm 0.480$ & $1.49 \pm 0.341$ & $\mathrm{p}<0.05$ \\
\hline Stroma & $10.44 \pm 0.541$ & $13.37 \pm 1.104$ & $\mathrm{p}<0.05$ \\
\hline \multicolumn{4}{|c|}{ Total volume $\left(\mathrm{mm}^{3}\right)$} \\
\hline Mixed acini & $51.59 \pm 1.510$ & $40.01 \pm 1.432$ & $\mathrm{p}<0.01$ \\
\hline Intercalated duct & $0.34 \pm 0.035$ & $0.24 \pm 0.032$ & $\mathrm{p}<0.05$ \\
\hline Striated duct & $2.23 \pm 0.338$ & $1.41 \pm 0.164$ & $\mathrm{p}<0.05$ \\
\hline Excretory duct & $1.81 \pm 0.318$ & $0.71 \pm 0.137$ & $\mathrm{p}<0.05$ \\
\hline Stroma & $6.40 \pm 0.277$ & $6.67 \pm 0.693$ & $\mathrm{p}>0.05$ \\
\hline \multicolumn{4}{|c|}{ Cell number $\left(\times 10^{5}\right)$} \\
\hline Mucous cells & $112.87 \pm 15.127$ & $113.95 \pm 3.353$ & $p>0.05$ \\
\hline Serous demilune cells & $56.62 \pm 2.564$ & $50.15 \pm 3.806$ & $p>0.05$ \\
\hline Intercalated duct cells & $3.51 \pm 0.571$ & $2.32 \pm 0.334$ & $p>0.05$ \\
\hline Striated duct cells & $10.31 \pm 1.381$ & $9.12 \pm 0.905$ & $p>0.05$ \\
\hline Excretory duct cells & $8.02 \pm 1.149$ & $2.74 \pm 0.293$ & $\mathrm{p}<0.05$ \\
\hline \multicolumn{4}{|c|}{ Cell volume $\left(\mu \mathrm{m}^{3}\right)$} \\
\hline Mucous cells & $1,870.78 \pm 68.970$ & $1,650.21 \pm 64.802$ & $\mathrm{p}<0.05$ \\
\hline Serous demilune cells & $635.27 \pm 16.726$ & $876.41 \pm 76.767$ & $\mathrm{p}<0.05$ \\
\hline Intercalated duct cells & $285.77 \pm 38.547$ & $215.37 \pm 45.187$ & $\mathrm{p}>0.05$ \\
\hline Striated duct cells & $1,053.53 \pm 56.567$ & $792.115 \pm 49.965$ & $\mathrm{p}<0.05$ \\
\hline Excretory duct cells & $982.11 \pm 60.65$ & $667.59 \pm 54.368$ & $\mathrm{p}<0.05$ \\
\hline \multicolumn{4}{|c|}{ Total surface $\left(\mathrm{cm}^{2}\right)$} \\
\hline Mixed acini & $33.80 \pm 1.367$ & $30.77 \pm 1.586$ & $\mathrm{p}>0.05$ \\
\hline Intercalated duct & $0.52 \pm 0.124$ & $0.38 \pm 0.090$ & $p>0.05$ \\
\hline Striated duct & $1.34 \pm 0.171$ & $1.22 \pm 0.172$ & $\mathrm{p}>0.05$ \\
\hline Excretory duct & $0.75 \pm 0.087$ & $0.43 \pm 0.0515$ & $\mathrm{p}<0.01$ \\
\hline \multicolumn{4}{|c|}{ Surface-to-volume ratio $\left(\mathrm{cm}^{2} / \mathrm{cm}^{3}\right)$} \\
\hline Mixed acini & $659.30 \pm 38.38$ & $766.66 \pm 24.397$ & $\mathrm{p}<0.05$ \\
\hline Intercalated duct & $1,836.37 \pm 197.930$ & $1,810.56 \pm 17.962$ & $\mathrm{p}>0.05$ \\
\hline Striated duct & $620.07 \pm 52.25$ & $835.84 \pm 65.089$ & $\mathrm{p}<0.01$ \\
\hline Excretory duct & $457.85 \pm 62.700$ & $561.44 \pm 72.596$ & $\mathrm{p}>0.05$ \\
\hline
\end{tabular}

${ }^{*}$ Mean \pm standard error of 6 animals.

but required other more sensitive methods for the characterization of these differences ${ }^{10,14,16,22}$. Among these methods, stereology has attracted attention due to its sensitivity and precision, permitting the determination of volumetric, superficial, linear and numerical dimensions of different structures and/ or cells present in an organ ${ }^{1}$.

In this respect, previous studies carried out in our laboratory using this methodology have permitted, for example, the demonstration that sexual dimorphism in the mouse submandibular gland is not restricted to the convoluted granular tubules but is also present in the acini, intercalated ducts, striated ducts, excretory ducts and stroma ${ }^{15}$; that no sexual dimorphism is present in the granular or striated ducts of the rat submandibular gland ${ }^{23}$, 

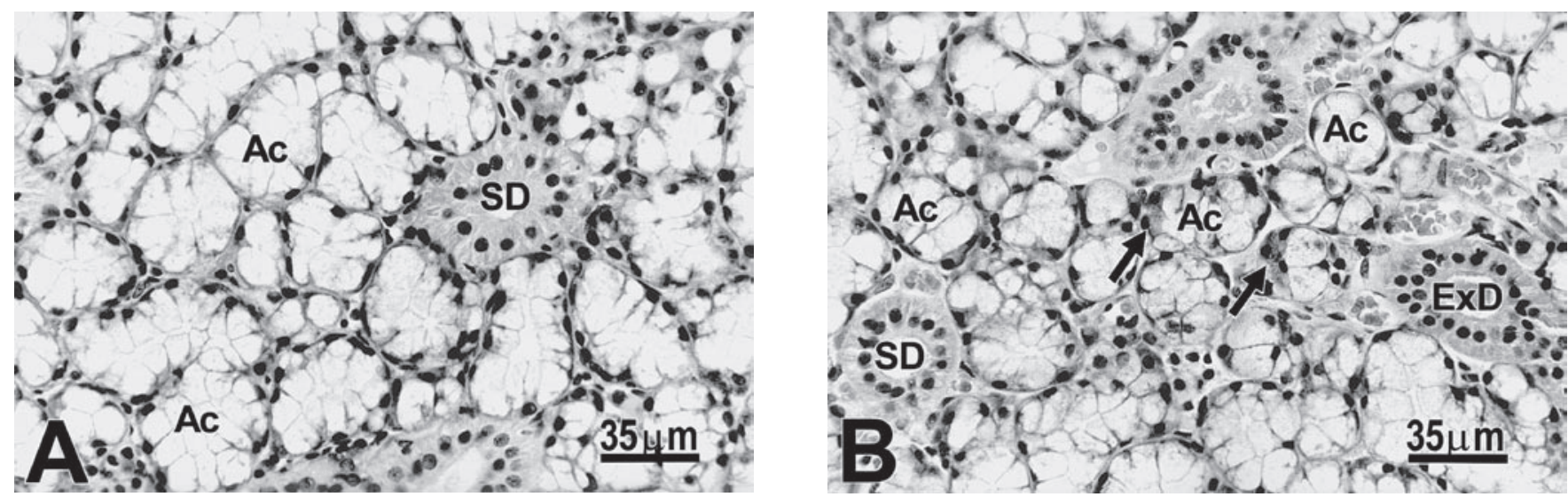

FIGURE 1 - Sublingual gland of male (A) and female (B) rats, 120 days old. Observe that the diameter and cell volume in the acini (Ac) and striated ducts (SD) are large in the male gland. The serous demilune cells (arrows) are rarely observed in male. Transections of excretory ducts (ExD) are seen in B. (H. E.).

while sexual differences exist in the acini, intercalated ducts, excretory ducts and stroma ${ }^{4}$; and that in the mouse parotid gland the acini and intercalated ducts are more developed in males ${ }^{20}$.

With respect to the sublingual gland of rodents, evidence for the occurrence of sexual dimorphism detected solely by histochemical methods has only been provided for the mouse ${ }^{22}$ and hamster ${ }^{10}$, while no study is available regarding the presence of sexual differences in the rat sublingual gland.

With respect to its structure, the rat sublingual gland consists predominantly of mucous cells arranged in tubuloacinar structures which are surrounded by few serous cells arranged in demilunes ${ }^{6,17}$. The mucous acinar cells produce and secrete sublingual mucins or mucous glycoproteins ${ }^{13,28}$, while the serous demilune cells secrete common salivary protein 1 (CSP-1), and neonatal submandibular gland secretory proteins B (SMGB) and $\mathrm{D}$ (SMGD) $)^{2,3,7,12}$. The innervation of these cells is mainly parasympathetic ${ }^{27}$ and they rapidly respond to stimulation with secretagogues ${ }^{6}$.

In order to exclude alterations in the results due to seasonal influences, all rats used in the present study came from a lot born on the same day and thus were of the same age. Mean body mass of the female rats used here was $40 \%$ lower than that of male animals, while absolute glandular mass showed a significant difference of only $21 \%$. In this respect, relative glandular mass was 31\% higher in females, i.e., females had larger glands than males in relation to their body mass.

Relative volumetric analysis showed no significant differences in volume density between genders for the acini, intercalated ducts or stri- ated ducts, indicating a similar volumetric ratio for these structures in males and females. A significant difference in volume density was only observed for the excretory duct and stroma compartments, which were higher in males and females, respectively.

The absolute volume of all morphological compartments, except for the stroma, was higher in male rats. These differences are due to the fact that glandular mass was higher in males, and that the fractions of glandular volume occupied by the acini and intercalated and striated ducts were the same in males and females.

It should be noted that the absolute volume of each compartment depends on the number of cells and on their volume. An interesting aspect is the fact that the number of cells of the acini, intercalated ducts or striated ducts did not differ between genders, suggesting that the differences in the absolute volume of these compartments were related to variations in the individual volume of these cells. This hypothesis was confirmed for mucous acinar cells and striated duct cells, which presented 13 and 33\% higher cell volumes in males, respectively. With respect to the serous demilune cells, a 38\% higher cell volume was observed for females.

The surface-to-volume ratio, a relative morphometric parameter related to the shape and size of the structure, was found to be 16 and 35\% higher in females for the acini and striated ducts, respectively. Since the shape of these structures is similar in the two genders, the differences observed indicate that the female acini and striated ducts have a smaller diameter than the same structures in males. 
Lima MC, Sottovia-Filho D, Cestari TM, Taga R. Morphometric characterization of sexual differences in the rat sublingual gland. Braz Oral Res 2004;18(1):53-8.

\section{CONCLUSION}

The present results led us to conclude that the sublingual gland of female rats possesses smaller mixed acini and shorter and narrower-caliber striated ducts, smaller mucous acinar cells and larger serous demilune cells than the male gland, indicating the presence of sexual dimorphism as well as suggesting sexual differences in the quality of the

\section{REFERENCES}

1. Aherne W, Dunnil MS. Morphometry. London: Edward Arnold; 1982.

2. Ball WD, Hand AR, Johnson AO. Secretory proteins as markers for cellular phenotypes in rat salivary glands. Dev Biol 1988;125:265-79.

3. Ball WD, Hand AR, Moreira JE. A neonatal secretory protein associated with secretion granule membranes in developing rat salivary glands. J Histochem Cytochem 1991;39:1693-706.

4. Barbosa DB, Hassunuma RM, Taga R. Estudo morfométrico e bioquímico do crescimento das glândulas sublinguais do rato durante a vida pós-natal. Rev Ciênc Biomed 1997;18:83-94.

5. Chretien M. Action of testosterone on the differentiation and secretory activity of a target organ: the submaxillary gland of the mouse. Int Rev Cytol 1977;50:333-96.

6. Culp DJ, Graham LA, Latchney LR, Hand AR. Rat sublingual gland as a model to study glandular mucous cell secretion. Am J Physiol 1991;260:1233-44.

7. Girard LR, Castle AM, Hand AR, Castle JD, Mirels L. Characterization of common salivary protein 1 , a product of rat submandibular, sublingual, and parotid glands. J Biol Chem 1993;268:26592-601.

8. Hassunuma RM, Taga R. Allometric study of the postnatal development of the rat sublingual glands. Okajimas Folia Anat Jpn 1996;73:265-71.

9. Hernandes R, Bassi WE, Stipp ACM, Taga R. Estudo estereológico dos ácinos de glândulas sublinguais de ratos jovens e adultos. Rev Ciên Biomed 1995;15:31-9.

10. Kronman JH. Hamster salivary gland sexual dimorphism. I. Protein histochemical study. J Dent Res 1963;42:1237.

11. Lacassagne A. Dimorphisme sexuel de la glande sousmaxillaire chez la souris. C R Soc Biol 1940;133:180-1.

12. Mirels L, Miranda JA, Ball WD. Characterization of the rat salivary gland B1-immunoreactive proteins. Biochem J 1998;330:437-44.

13. Moschera J, Pigman W. The isolation and characterization of rat sublingual mucus-glycoprotein. Carbohydr Res 1975;40:53-67.

14. Mudd BD, White SC. Sexual dimorphism in the rat submandibular gland. J Dent Res 1975;54:193.

15. Pardini LC, Taga R. Stereological study of the sexual dimorphism in mouse submandibular glands. Okajimas Folia Anat Jpn 1996;73:119-24.

16. Pinkstaff CA. Sexual dimorphism of the miniature pig saliva secreted by the gland.

\section{ACKNOWLEDGEMENTS}

The authors would like to thank the CNPq (PIBIC - Brazilian National Council for Research and Scientific Development) and FAPESP (The State of São Paulo Research Foundation) (grant 95/093711 and 99/11597-9) for financial support. submandibular glands. Am J Anat 1972;135:371-9.

17. Pinkstaff CA. The cytology of salivary glands. Int Rev Cytol 1980;63:141-261.

18. Raynaud J. Controle hormonal de la glande sous-maxillaire de la souris. Bull Biol Fr Belg 1960,94:399-523.

19. Redman RS, Ball WD. Cytodifferentiation of secretory cells in the sublingual gland of the prenatal rat: a histological, histochemical and ultrastructural study. Am J Anat 1978;153:367-89.

20. Ribeiro TT, Cestari TM, Taga R. Morphometric dimensions of the mouse parotid glands of both sexes. Ital $\mathrm{J}$ Anat Embryol 2001;106:27-34

21. Riva A, Tandler B, Testa Riva F. Ultrastructural observations on human sublingual gland. Am J Anat 1988;181:385-92.

22. Spicer SS. The use of various cationic reagents in histochemical differentiation of mucopolysaccharides. Am J Clin Pathol 1961;36:393-407.

23. Taga R, Achôa AS, Pardini LC. Estudo estereológico dos ductos granulosos e estriados de glândulas submandibulares de ratos machos e fêmeas. Rev FOB 1994;2:22-7.

24. Taga R, Sesso A. Avaliação do número de células de órgãos pela dosagem bioquímica de DNA em homogeneizados e por contagem direta através de métodos morfométricos. Ciênc Cult 1978;30:1232-6.

25. Taga R, Sesso A. Postnatal development of the rat sublingual glands. A morphometric and radioautographic study. Arch Histol Cytol 1998;61:417-26.

26. Taga R, Sesso A. Ultrastructure of the rat sublingual gland during period of high proliferative activity in postnatal development. Braz J Morphol Sci 2002;19:55-62.

27. Templeton D, Thulin A. Secretory, motor and vascular effects in the sublingual gland of the rat caused by autonomic nerve stimulation. Q J Exp Physiol Cogn Med Sci 1978;63:59-66.

28. Watson GE, Latchney LR, Luo W, Hand AR, Culp DJ. Biochemical and immunological studies and assay of rat sublingual mucins. Arch Oral Biol 1997;42:161-72.

29. Weibel ER. Stereological principles of morphometry in electron microscopic cytology. Int Rev Cytol 1969;26:235302.

30. Wolff MS, Mirels L, Lagner J, Hand AR. Development of the rat sublingual gland: a light and electron microscopic immunocytochemical study. Anat Rec 2002;266:30-42.

Received for publication on Feb 10, 2003 Sent for alterations on Nov 18, 2003 Accepted for publication on Dec 05, 2003 